ISSN 1991- 8690

website :http:// jsci.utq.edu.iq

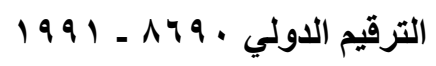

Email: utjsci@utq.edu.iq

\title{
Syntheses, Characterization and biological Activity of a new ligand [N-(5-sulfanyl-1,3,4- thiadiazol-2-yl)acetamide with some transition metal complexes
}

weam .A. Salman*

University of Thi-Qar/College of Science*

ibrahim_flifel@yahoo.com

\author{
Ibrahim .A. flifel**
}

\author{
Mohsin .E.Al-Dokheily* \\ Technical Institute of Shatra** \\ mohsinaldokheily@yahoo.co.uk
}

\section{Abstract:-}

A-new series of transition metal (Cr(III), Fe(III), $\mathrm{Co}(\mathrm{II}), \mathrm{Ni}(\mathrm{II})$ and $\mathrm{Cu}(\mathrm{II})$ ) complexes of ligand [N-(5-sulfonyl$1,3,4$,thiadiazol-2-yl)acetamide were synthesized. All the synthesized complexes were characterized by analytical techniques, magnetic susceptibility measurements, elemental analyses, conductance, IR, 1HNMR and mass spectra. The electrolytic behavior were confirmed from their conductance data. It may be concluded that the ligand coordinate through Nitrogen and sulfur atoms as shown in figure (6). for all complexes. The ligand acts as a didentate ligand coordinating through the sulfur[ $\left[\mathrm{S}^{6}\right]$ and the nitrogen atom of shiff base $\left[\mathrm{N}^{5}\right]$. This view is further supported by the appearance of a band corresponding to the metal-nitrogen stretching vibration at $(547-563) \mathrm{cm}^{-1}$ in the complexes. From results it was suggested tetrahedral geometry for $\mathrm{Ni}(\mathrm{II})$ and $\mathrm{Cu}$ (II) complexes, while $\mathrm{Cr}(\mathrm{III}), \mathrm{Fe}$ (III) and $\mathrm{Co}$ (III)complexes were assigned octahedral geometrics. All complexes and their parent organic moiety have been screened for antibacterial by using spread method and measurement inhibition zone by using (DMSO). this study showed positivity results, by comparison of inhibition zone with E-coli and staph aurens.

\section{تحضير وتثخيص ودراسة الفعالية البايولوجية لليكاند}

\section{[N-(5-sulfanyl-1,3,4-thiadiazol-2-yl)acetamide مع بعض معقدات العناصر الانتقالية}

$$
\text { كلية العلوم-قسم الكيمياء الدخيلي }
$$

mohsinaldokheily@yahoo.co.uk

$$
\text { الدراهيم عبود فليفل }
$$

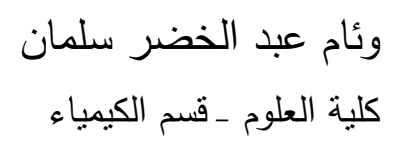

ibrahim_flifel@yahoo.com

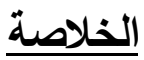

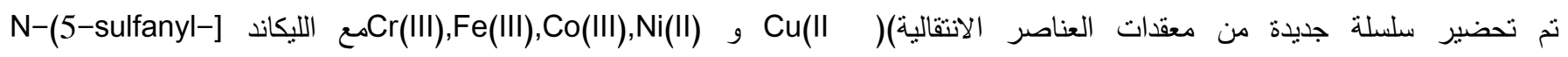

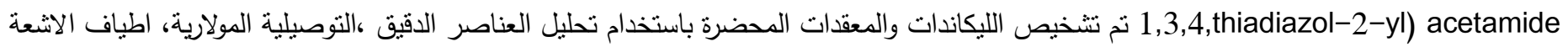
تحت الحمراء، وبروتون الرنين النووي المغناطيسي وطيف الكتلة. السلوك الاكتروليتي للمعقدات تم تاكيده باستخدام تقنية التوصيل المولاري .وتم الاستتناج

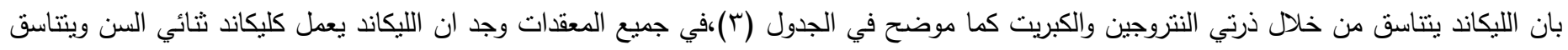

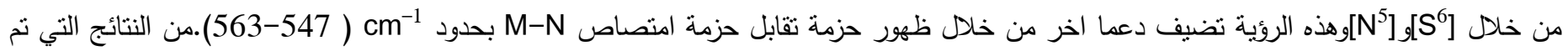

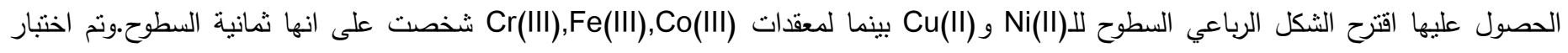
الفعالية البايولوجية لليكاند المحضر ومعقداته باستخدام طريقة الانتشار وذلك بقياس منطقة النتبيط وباستخدام مذيب ثنائي مثيل اوكسيد الكبريت (DMSO) ،

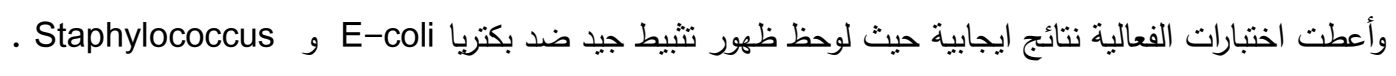




\section{1- Introduction}

Over the past decade, drug resistance has become a growing problem in the treatment of infectious disease caused by bacteria, fungi and viruses. In particular, resistance of bacterial pathogens to current antibiotic has emerged as a major health problem. This is especially true in case of infectious diseases such as pneumonia,meningitis and tuberculosis. The search for new antimicrobial agent is one of the most challenging tasks to the medicinal chemist . Heterocyclic moieties can be found in a large number of compounds which display biological activity. The biological activity of the compounds is mainly dependent on their molecular structures (1) .Thiadiazoles are very interesting compounds due to their important applications. In recent years 1, 3, 4-Thiadiazole derivatives have received significant attention and have been increasingly investigated due to their diverse range of biological properties. They exhibit for example, antimicrobial $^{(2)}$, anti-micro bacterial ${ }^{(3)}$, anticancer ${ }^{(4)}$, anti-inflammatory (5) .The compounds containing azomethine group (-CH=N-) are known as Schiff bases. They are used as substrates in the preparation of number of industrial and biologically active compounds via ring closure, cyclo-addition and replacement reactions ${ }^{(6)}$ Schiff base ligands are potentially capable of forming stable complexes with most transition metal ions, which served as model compounds for biologically important species .aimed at searching for novel antibacterial antiviral agents with high activity and low toxicity, a synthetic route has been developed to the title compounds.

\section{Experimental}

\section{Materials}

All the employed chemicals were of reagent grade, Thiosemicarbazide (Fluka) Hydrazine hydrate(BDH), anhydrous sodium carbonate (Fluka), absolute ethanol $(\mathrm{BDH})$, Hydro chloride acid(BDH), Ethyl acetate $(\mathrm{BDH})$ and carbon disulphide $(\mathrm{BDH})$ were used. All the metal chlorides $\left(\mathrm{NiCl}_{2} \cdot 6 \mathrm{H}_{2} \mathrm{O}, \mathrm{CuCl}_{2} \cdot 6 \mathrm{H}_{2} \mathrm{O}\right.$, $\mathrm{CrCl}_{3} 6 \mathrm{H}_{2} \mathrm{O}, \mathrm{CoCl}_{3} \cdot 6 \mathrm{H}_{2} \mathrm{O}, \mathrm{FeCl}_{3} 6 \mathrm{H}_{2} \mathrm{O}$ ) were purchased from $(\mathrm{BDH})$ fine chemicals.

Analytical methods and physical measurements Elemental $\mathrm{C}, \mathrm{H}$ and $\mathrm{N}$ analysis were carried out on a Thermofinigan flash analyzer, the FTIR spectra in the range (200-4000) $\mathrm{cm}^{-1}$ were recorded as CsI discs using a Shimadzu FTIR spectrophotometer, molar conductance measurements were made in anhydrous DMSO at $25{ }^{\circ} \mathrm{C}$ using Inolabcond 720.The ${ }^{1} \mathrm{H}$ NMR spectra were recorded on a Mercury-300BB NMR 300 spectrometer, relative to the internal standard tetra methyl silane (TMS) , d6-DMSO used as solvent. Melting points were determined in open capillary tubes using an electro thermal melting point /SMP3Iapparatus. Mass spectra were recorded in the range $(0-800) \mathrm{m} / \mathrm{e}$ on a 5973 network mass selective detector .

\subsection{Preparation of the ligand}

New ligand [N-(5-sulfonyl-1,3,4,thiadiazol-2-yl) acetamide (Scheme 1) was prepared as follows:

A mixture of $(9.1 \mathrm{~g}, 0.1 \mathrm{~mol})$ of thiosemicarbazide and (4 g, $0.1 \mathrm{~mol}$ ) of anhydrous sodium carbonate was dissolved in $(70 \mathrm{ml})$ absolute ethanol, to this solution (6 $\mathrm{ml}, 0.1 \mathrm{~mol}$ ) of carbon disulfide was added. The resulting mixture was heated under reflux for $(6$ hours).The resultant mixture was concentrated, and carefully acidified with hydrochloric acid $\mathrm{HCl}(10 \%)$ to give pale yellow precipitate. The crude product was filtered and washed with cold water, recrystallized from ethanol to give the desired product5-Amino-1,3,4thiadiazole-2-thiol (A1) as White needles $(7,8)$, yield (81\%),m.p(9).233-235C.A mixture(A1) (0.02mol, 2gm) and Ethyl acetate $(0.02 \mathrm{~mol}, 2 \mathrm{ml})$ dissolved in ethanol $(50 \mathrm{ml})$ was refluxed on a water bath for(3) hrs, The resultant mixture[ligand] was concentrated and the Yellow solid which separated was filtered and recrystallised from ethanol. Yield: $(86 \%)$, m. p. 272$274^{\circ} \mathrm{C}$. (scheme 1$)$

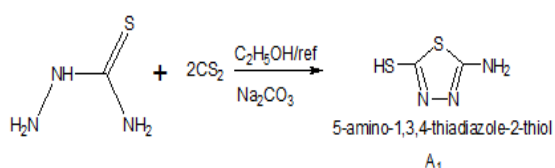

$A_{1}$

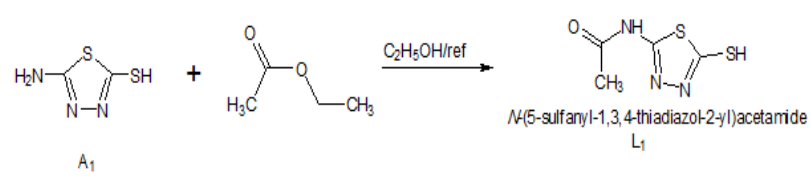

Scheme (1) preparation of ligand

\subsection{Preparation of complexes}

The $\mathrm{Cr}(\mathrm{III}), \mathrm{Co}(\mathrm{III}), \mathrm{Fe}(\mathrm{III}), \mathrm{Ni}$ (II) and $\mathrm{Cu}(\mathrm{II})$ complexes were prepared by refluxing the respective hydrated metal chloride ( $1 \mathrm{mmol}, 0.28 \mathrm{gm})$ in $15 \mathrm{ml}$ ethanol with $50 \mathrm{ml}$ of an ethanolic solution of the ligand (1mmol, $0.3 \mathrm{gm}$ ) for $4 \mathrm{hrs}$. The resultant solids 
which separated were filtered, washed with ethanol and dried in air.

\section{Results \& Discussion}

The purity of the ligand and its complexes were checked by TLC using silica gel-G as adsorbent., elemental analysis tabulated in Table (1), Melting point, physical properties and molar conductance of all the compounds studied are tabulated in Table (2). The calculated values were in a good agreement with the experimental values.

Table 1.Elemental analysis for the ligand

\begin{tabular}{|l|l|l|l|l|l|}
\hline \multicolumn{2}{|l|}{ Experimental } & \multicolumn{3}{l|}{ Theoretical } \\
\hline $\mathrm{C} \%$ & $\mathrm{H} \%$ & $\mathrm{~N} \%$ & $\mathrm{C} \%$ & $\mathrm{H} \%$ & $\mathrm{~N} \%$ \\
\hline 27.42 & 2.937 & 24.064 & 27.42 & 2.88 & 23.98 \\
& & & & & \\
\hline \hline
\end{tabular}

Table 2. conductance, physical properties data of the ligand and its complexes

\begin{tabular}{|c|l|c|l|c|l|}
\hline No & Compound & Molecular formula & Color & $\begin{array}{l}\Lambda \\
\text { Scm2 } \\
\text { mol-1 }\end{array}$ & $\begin{array}{l}\text { Melting } \\
\text { Point }\end{array}$ \\
\hline 1 & Ligand & $\mathrm{C}_{4} \mathrm{H}_{5} \mathrm{~N}_{3} \mathrm{~S}_{2} \mathrm{O}$ & Yellow & --- & $272-274$ \\
\hline 2 & {$[\mathrm{Cr}(\mathrm{L}) 2 \mathrm{Cl} 2] \mathrm{Cl}$} & $\begin{array}{c}\mathrm{Cr}\left(\mathrm{C}_{4} \mathrm{H}_{5} \mathrm{~N}_{3} \mathrm{~S}_{2} \mathrm{O}\right)_{2} \\
\mathrm{Cl}_{3}\end{array}$ & $\begin{array}{c}\text { Light } \\
\text { green }\end{array}$ & 39.2 & $294-296$ \\
\hline 3 & {$[\mathrm{Co}(\mathrm{L}) 2 \mathrm{Cl} 2] \mathrm{Cl}$} & $\begin{array}{c}\mathrm{Co}\left(\mathrm{C}_{4} \mathrm{H}_{5} \mathrm{~N}_{3} \mathrm{~S}_{2} \mathrm{O}\right)_{2} \\
\mathrm{Cl}_{3}\end{array}$ & $\begin{array}{c}\text { Dark } \\
\text { brown }\end{array}$ & 31.2 & $310 \mathrm{~d}^{*}$ \\
\hline 4 & {$[\mathrm{Fe}(\mathrm{L}) 2 \mathrm{Cl} 2] \mathrm{Cl}$} & $\begin{array}{c}\mathrm{Fe}\left(\mathrm{C}_{4} \mathrm{H}_{5} \mathrm{~N}_{3} \mathrm{~S}_{2} \mathrm{O}\right)_{2} \\
\mathrm{Cl}_{3}\end{array}$ & $\begin{array}{c}\text { Light } \\
\text { Brown }\end{array}$ & 34.7 & $288-290$ \\
\hline 5 & {$[\mathrm{Cu}(\mathrm{L}) \mathrm{Cl} 2]$} & $\begin{array}{c}\mathrm{Cu}\left(\mathrm{C}_{4} \mathrm{H}_{5} \mathrm{~N}_{3} \mathrm{~S}_{2} \mathrm{O}\right) \\
\mathrm{Cl}_{2}\end{array}$ & $\begin{array}{c}\text { Greenish } \\
\text { yellow }\end{array}$ & 9.8 & $335-337$ \\
\hline 6 & {$[\mathrm{Ni}(\mathrm{L}) \mathrm{Cl} 2]$} & $\begin{array}{c}\mathrm{Ni}\left(\mathrm{C}_{4} \mathrm{H}_{5} \mathrm{~N}_{3} \mathrm{~S}_{2} \mathrm{O}\right) \\
\mathrm{Cl}_{2}\end{array}$ & $\begin{array}{c}\text { Light } \\
\text { green }\end{array}$ & 10.1 & $266-268$ \\
\hline \hline
\end{tabular}

$\mathrm{d}^{*}=$ decomposition

The FTIR spectrum for $\mathrm{L}$ shows a characteristic stretching absorption bands at $3286 \mathrm{~cm}^{-1}, 2700 \mathrm{~cm}^{-}$ ${ }^{1}, 1593 \mathrm{~cm}^{-1}, 1504 \mathrm{~cm}^{-1}, 1365 \mathrm{~cm}^{-1}$ and $1323 \mathrm{~cm}^{-1}$ assigned to $v(\mathrm{~N}-\mathrm{H}) \quad, \mathrm{v}(\mathrm{S}-\mathrm{H}) \cdot(\mathrm{C}=\mathrm{O}), \mathrm{v}(\mathrm{C}=\mathrm{N})$, asymmetrical $\mathrm{C}-\mathrm{S}-\mathrm{C}$ and symmetrical $\mathrm{C}-\mathrm{S}-\mathrm{C}$ stretching respectively ${ }^{(10)}$. The $\mathrm{C}=\mathrm{N}$ and $\mathrm{S}-\mathrm{H}$ stretching are important to predict the bonding mode of the ligand ,these bands shift lower wavelength in the spectra of complexes compare with ligand, observed changes are the evidences of complexation had happened. The IR data of the ligand and complexes are shown in Table (3) and figure(8),(9)and(10). The Table lists the wave number (v) for some of the characteristics groups exhibited by the ligand and complexes.
Table 3: Characteristic absorption bands of ligand and its complexes

\begin{tabular}{|c|c|c|c|c|c|c|c|c|c|}
\hline No & $\mathrm{vN}-\mathrm{H}$ & vS - H & $v \mathrm{C}=0$ & $v \mathrm{C}=\mathrm{N}$ & v C-S-C & الهيكلية & $v M-N$ & vMI-S & vM-Cl \\
\hline L & 3286 & 2700 & 1593 & 1504 & $\begin{array}{l}1365 \text { asy } \\
1323 \text { sy }\end{array}$ & 1026 & & & \\
\hline 1 & 3263 & 2800 & 1608 & 1554 & $\begin{array}{l}1365 \text { asy } \\
1334 \text { sy }\end{array}$ & 1056 & 550 & 432 & 250 \\
\hline 2 & 3275 & 2805 & 1639 & 1504 & $\begin{array}{l}\text { 1392asy } \\
1319 \text { sy }\end{array}$ & 1138 & 547 & 412 & 212 \\
\hline 3 & 3309 & 2750 & 1589 & 1523 & $\begin{array}{l}\text { 1392asy } \\
1338 \text { sy }\end{array}$ & 1037 & 559 & 412 & 231 \\
\hline 4 & 3286 & 2802 & 1608 & 1523 & $\begin{array}{l}1400 \text { asy } \\
1354 \text { sy }\end{array}$ & 1053 & 563 & 412 & 270 \\
\hline 5 & 3255 & 2750 & 1620 & 1516 & $\begin{array}{l}\text { 1354asy } \\
1320 \text { sy }\end{array}$ & 1049 & 563 & 412 & 277 \\
\hline
\end{tabular}

The data of proton NMR of the ligand[N-(5-sulfanyl1,3,4,thiadiazol-2-yl) acetamide displayed good solubility in DMSO. The proton nuclear magnetic resonance spectral data gave additional support for the suggested structure of the ligand. The spectra also exhibit a singlet $-\mathrm{CH} 3$ peaks at $2.504 \mathrm{ppm}$ due to methyl group, another singlet peaks exhibit at $3.845 \mathrm{ppm}$ and $5.793 \mathrm{ppm}$ due to-SH and $-\mathrm{NH}$ respectively(11). the proton NMR of the ligand shown in figure(11).The mass spectrum of the ligand exhibits a molecular ion peak $[\mathrm{M}]+$. at $\mathrm{m} / \mathrm{z} 175$,the ligand spectra shows fragment the spectra peaks at $\mathrm{m} / \mathrm{z}(160$, $142,131,102,99$ and 84$)$ due to $[(\mathrm{C} 3 \mathrm{H} 2 \mathrm{~N} 3 \mathrm{~S} 2 \mathrm{O})+$. ‘( $\mathrm{C} 4 \mathrm{H} 4 \mathrm{SN} 3 \mathrm{O})+$. ،( C3H5N3SO $)+$. ،(C3H4NSO $)+$. ‘( $\mathrm{C} 3 \mathrm{H} 5 \mathrm{~N} 3 \mathrm{O})+$. ‘(C3H4N2O $)+$. respectively as shown in Figure(12)and(Scheme2). The mass spectrum of the complex $[\mathrm{Cr}(\mathrm{L}) 2 \mathrm{Cl} 2] \mathrm{Cl}$ shows a molecular ion peak at $\mathrm{m} / \mathrm{z}[\mathrm{M} \cdot](507)$ which is equivalent to molecular mass of the complex. This complex shows another a fragmentation peak with loss of chlorine atom at $\mathrm{m} / \mathrm{z}(471)$. the complex spectrum shows fragment ion peak with loss two chlorine atom at $\mathrm{m} / \mathrm{z}(436,400)$ due to $[\mathrm{Cr}(\mathrm{L}) 2 \mathrm{Cl}]$ and $[\mathrm{Cr}(\mathrm{L}) 2]$ respectively. the complex spectrum shows fragment ion peak at $\mathrm{m} / \mathrm{z}$ (225) due to ([Cr (L1) ]+.). The mass spectrum of the complex $[\mathrm{Fe}(\mathrm{L}) 2 \mathrm{Cl} 2] \mathrm{Cl}$ shows a molecular ion peak at $\mathrm{m} / \mathrm{z}[\mathrm{M} \cdot]$ (511)which is equivalent to molecular mass of the complex. This complex shows another a fragment ion peak with loss of chlorine atom at $\mathrm{m} / \mathrm{z}(475)$. the complex spectrum shows fragment ion peak with loss two chlorine atom at $\mathrm{m} / \mathrm{z}(440,404)$ due to $\left[\mathrm{Fe}(\mathrm{L})_{2} \mathrm{Cl}\right]$ and $\left[\mathrm{Fe}(\mathrm{L})_{2}\right]$ respectively. the complex spectrum shows fragment ion peak at $\mathrm{m} / \mathrm{z}$ (336) due to $\left[\mathrm{Fe}\left(\mathrm{L}_{1}\right) \mathrm{Cl}_{2}\right]^{+} \mathrm{Cl}$. The mass spectrum of the complex $\left[\mathrm{Co}(\mathrm{L})_{2} \mathrm{Cl}_{2}\right] \mathrm{Cl}$ shows a molecular ion peak at $\mathrm{m} / \mathrm{z}[\mathrm{M} \cdot]$ (514)which is equivalent to molecular mass of the complex. This complex shows another a fragment ion 
peak with loss of chlorine atom at $\mathrm{m} / \mathrm{z}(478)$. the complex spectrum shows fragment ion peak with loss two chlorine atom at $\mathrm{m} / \mathrm{z}(443,407)$ due to $[\mathrm{Co}(\mathrm{L}) 2 \mathrm{Cl}]$ and $[\mathrm{Co}(\mathrm{L}) 2]$ respectively. the complex spectrum shows fragment ion peak at $\mathrm{m} / \mathrm{z}$ (232) due to ([Co (L1) ]+.).The mass spectrum of the complex [CuLCl2] shows a molecular ion peak at $\mathrm{m} / \mathrm{z}$ $[\mathrm{M} \cdot](309)$, This complex shows another a fragment ion peak with loss of chlorine atom at $\mathrm{m} / \mathrm{z}$ (273)and (238), the spectrum shows another peak at $\mathrm{m} / \mathrm{z}$ (133)due to $[\mathrm{Cu}$ $\mathrm{Cl} 2]+$.The mass spectrum of the complex [NiLCl2] shows a molecular ion peak at $\mathrm{m} / \mathrm{z}[\mathrm{M} \cdot]$ (304), This complex shows another a fragment ion peak with loss of chlorine atom at $\mathrm{m} / \mathrm{z}$ (267)and (233), the spectrum shows another peaks at m/z $(129,93)$ due to[Ni Cl2]+. ,[Ni Cl]+.. the mass spectra of the complexes shown in figure(13), (14),(15)(16)(17).

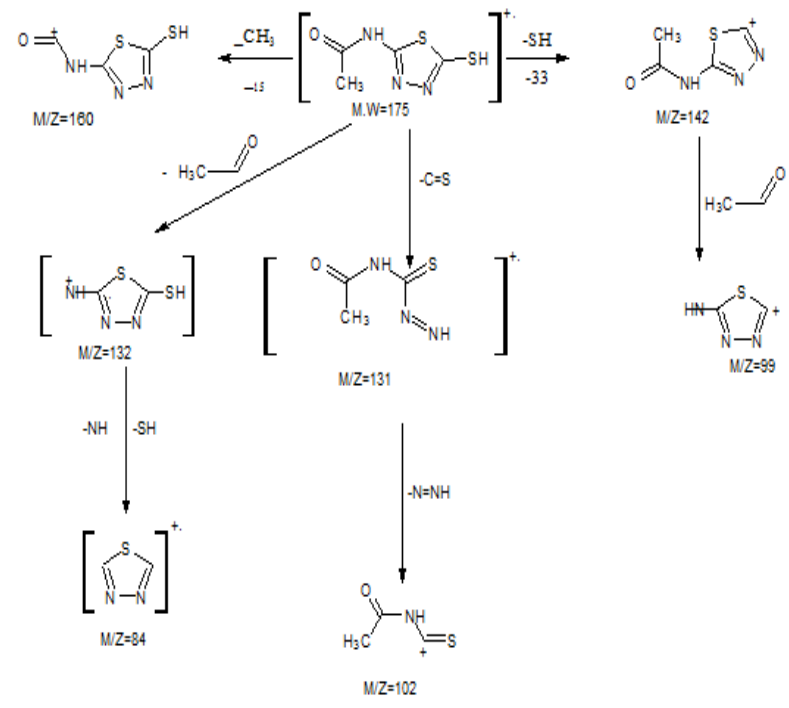

Scheme2(frigment of ligand)

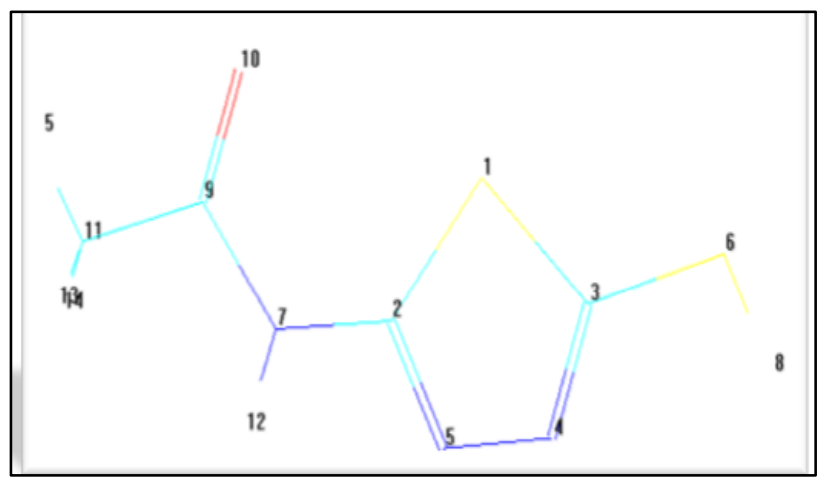

Figure 1:The stereochemistry of the Ligand

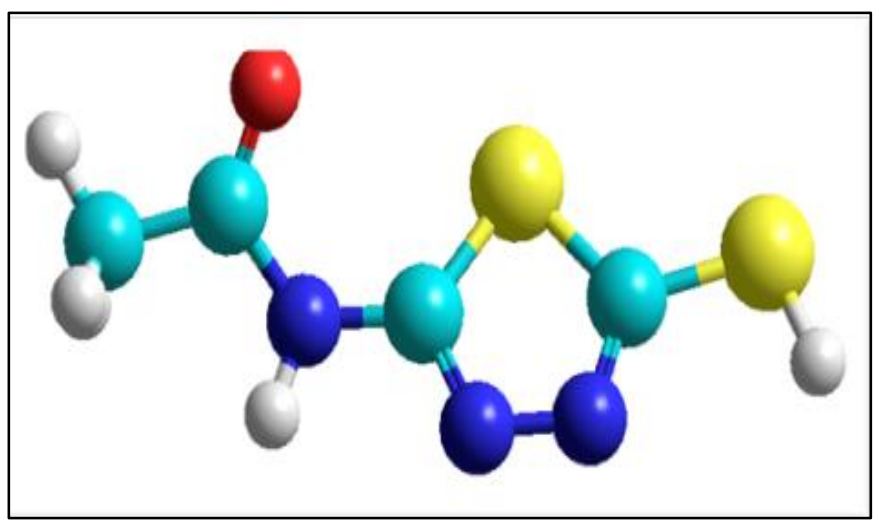

Figure 2: Graphical presentation of stereochemistry of the Ligand $\left(\mathrm{C}_{4} \mathrm{H}_{5} \mathrm{~N}_{3} \mathrm{~S}_{2} \mathrm{O}\right)$

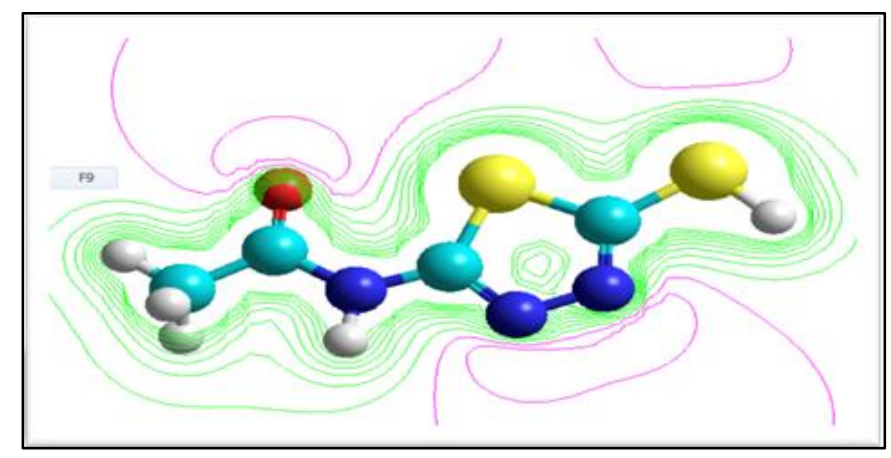

Figure 3:Electrostatic potential 2D for Ligand

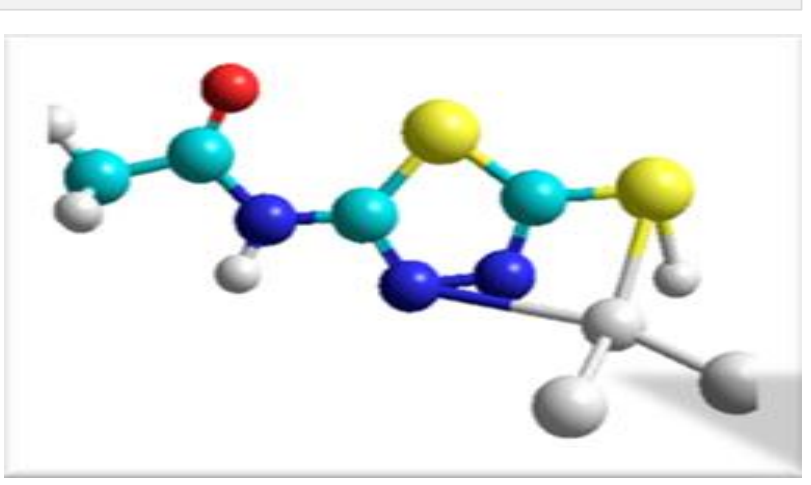

Figure 4: [ Ni(L) Cl2 ] 


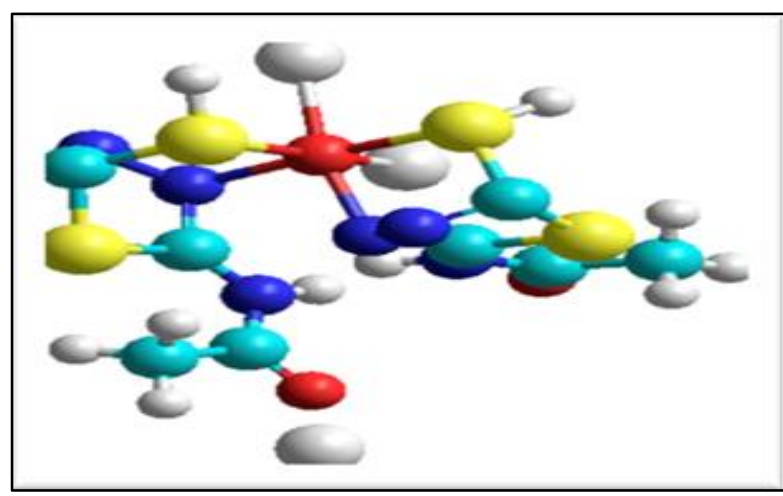

Figure5: $[\mathrm{Fe}(\mathrm{L}) 2 \mathrm{Cl} 2]$

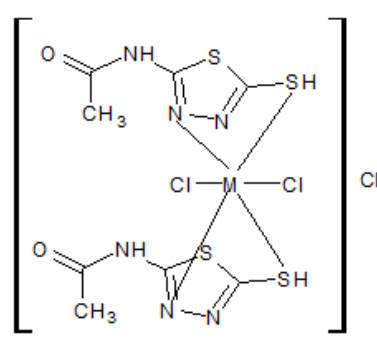

$\mathrm{M}=(\mathrm{Cr} \cdot \mathrm{Co} \cdot \mathrm{Fe})$

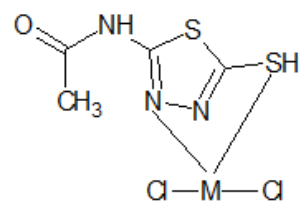

$\mathrm{M}=(\mathrm{Ni}, \mathrm{Cu})$
Figure 6:Analytical and spectral data $\left({ }^{1} \mathrm{H}\right.$ NMR,IR, mass spectra ) of all synthesized compounds were in full agreement with the proposed structure

\section{3-1 -Biological Activity}

The antibacterial activity of all the synthesized complexes were evaluated by using agar well diffusion method. All the microbial cultures were adjusted to 0.5 McFarland standard, which is visually comparable to a microbial suspension of approximately $1.5 \times 108$ cfu/mL. $20 \mathrm{~mL}$ of Mueller Hinton agar medium was poured into each Petri plate and plates were swabbed with $100 \mu \mathrm{L}$ inocula of the test microorganisms and kept for $15 \mathrm{~min}$ for adsorption. Using sterile cork borer of $8 \mathrm{~mm}$ diameter, wells were bored into the seeded agar plates, and these were loaded with a $100 \mu \mathrm{L}$ volume with concentration of $4.0 \mathrm{mg} / \mathrm{mL}$ of each compound reconstituted in the dimethyl sulphoxide (DMSO). All the plates were incubated at $37{ }^{\circ} \mathrm{C}$ for $24 \mathrm{hrs}$. Antibacterial activity of each compound was evaluated by measuring the zone of growth inhibition against the test organisms with zone reader (Hi Antibiotic zone scale). DMSO was used as a negative control whereas Ciprofloxacin was used as positive control. This procedure was performed in three replicate plates for each organism $(12,13)$.
Table 4 . Antibacterial screening data of the ligand and its metal complexes

\begin{tabular}{|c|c|c|}
\hline \hline Compound & $\begin{array}{c}\text { Escherichia coli } \\
\text { Inhibition zone }(\mathrm{mm})\end{array}$ & $\begin{array}{c}\text { Staphylococcus Aurens } \\
\text { Inhibition zone(mm) }\end{array}$ \\
\hline $\mathrm{L} 1=\mathrm{C}_{4} \mathrm{H}_{5} \mathrm{~N}_{3} \mathrm{~S}_{2} \mathrm{O}$ & $21++$ & $28++++$ \\
\hline $\mathrm{A}=\left[\mathrm{Cr}(\mathrm{L} 1)_{2} \mathrm{Cl}_{2}\right] \mathrm{Cl}$ & $18+$ & $20+++$ \\
\hline $\mathrm{B}=\left[\mathrm{Co}(\mathrm{L} 1)_{2} \mathrm{Cl}{ }_{2}\right] \mathrm{Cl}$ & $21++$ & $30++++$ \\
\hline $\mathrm{C}=[\mathrm{Cu}(\mathrm{L} 1) \mathrm{CL} 2]$ & $18+$ & $18++$ \\
\hline $\mathrm{D}=[\mathrm{Ni}(\mathrm{L} 1) \mathrm{Cl} 2]$ & $17+$ & $18++$ \\
\hline $\mathrm{E}=\left[\mathrm{Fe}(\mathrm{L} 1)_{2} \mathrm{Cl}{ }_{2}\right] \mathrm{Cl}$ & $17+$ & $30++++$ \\
\hline $\mathrm{Ciprofloxacin}$ & 35 & 25 \\
\hline \hline
\end{tabular}

$* *(+=$ Weak Inhibition,$++=$ Medium Inhibition,+++ $=$ Good Inhibition,$++++=$ Very good Inhibition)

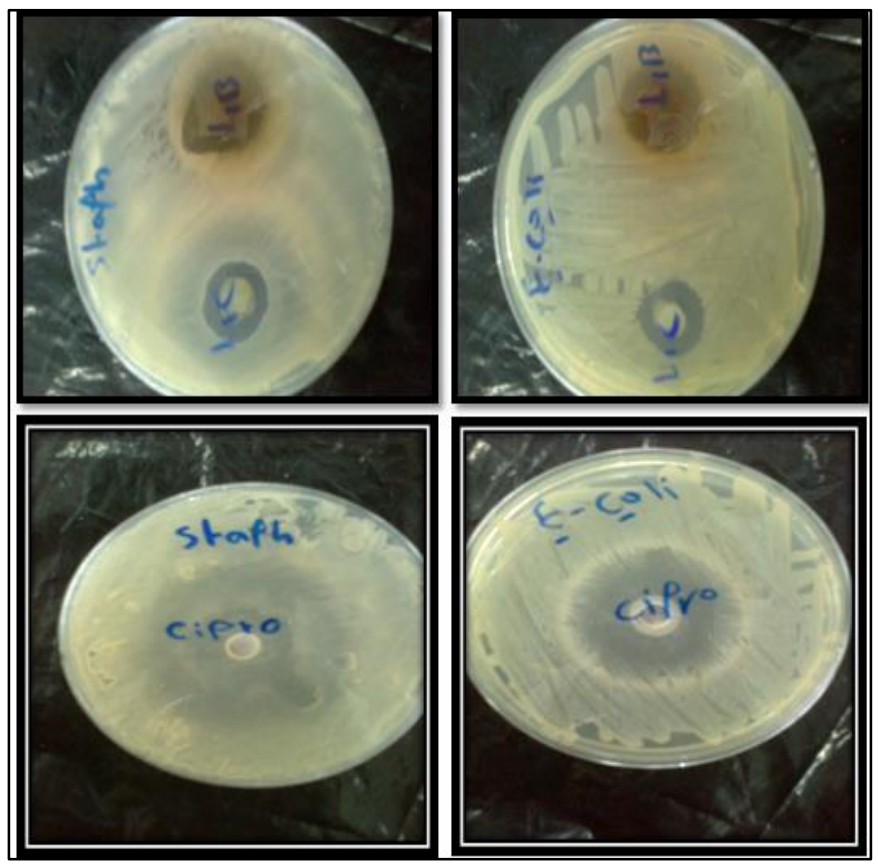

Figure (7)

\section{Conclusion}

The ligand [N-(5-sulfonyl-1,3,4,thiadiazol-2-yl) acetamide was successfully synthesized. The elemental analysis, , IR, ${ }^{1} \mathrm{H}$ NMR and mass spectral observations suggest the octahedral geometry for the $\mathrm{Cr}(\mathrm{III})$, $\mathrm{Co}(\mathrm{III}), \mathrm{Fe}(\mathrm{III})$. tetrahedral geometry was proposed for $\mathrm{Ni}(\mathrm{II}), \mathrm{Cu}(\mathrm{II})$. 


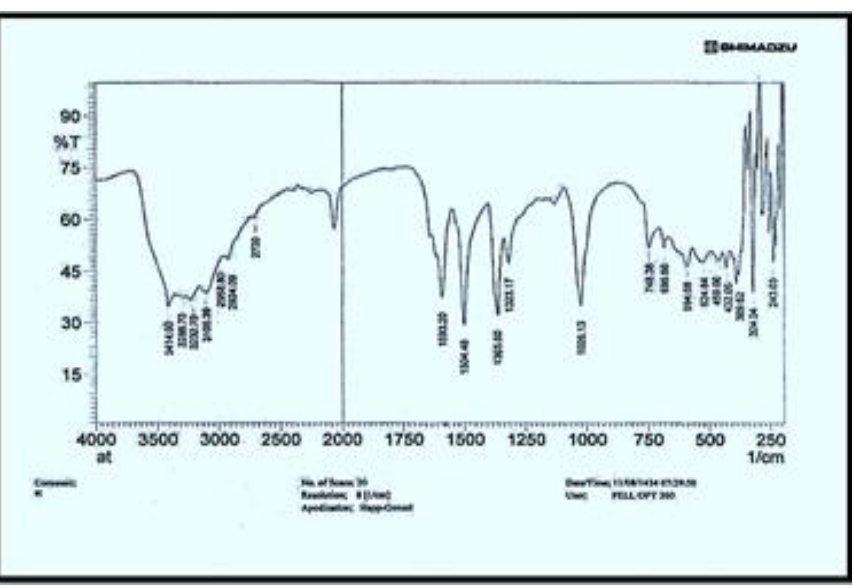

Figure 8: IR spectra of Ligand $\left(\mathrm{C}_{4} \mathrm{H}_{5} \mathrm{~N}_{3} \mathrm{~S}_{2} \mathrm{O}\right)$

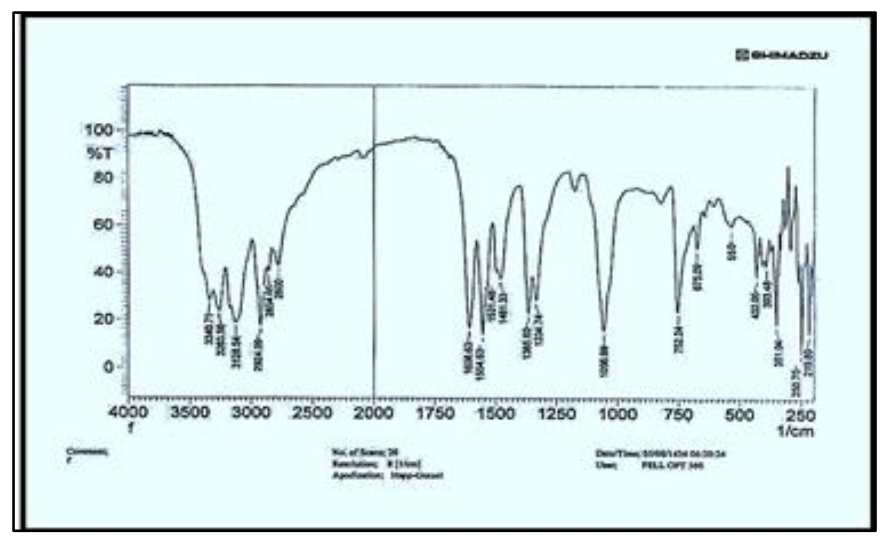

Figure 9: IR spectra of $\left[\mathrm{Cr}(\mathrm{L})_{2} \mathrm{Cl}_{2}\right]$

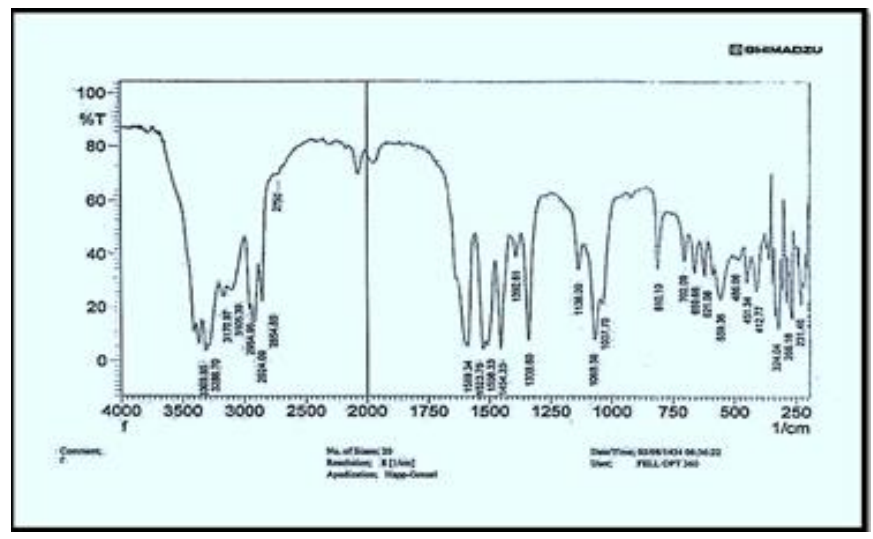

Figure 10: IR spectra of $[\mathrm{Co}(\mathrm{L}) 2 \mathrm{Cl} 2]$

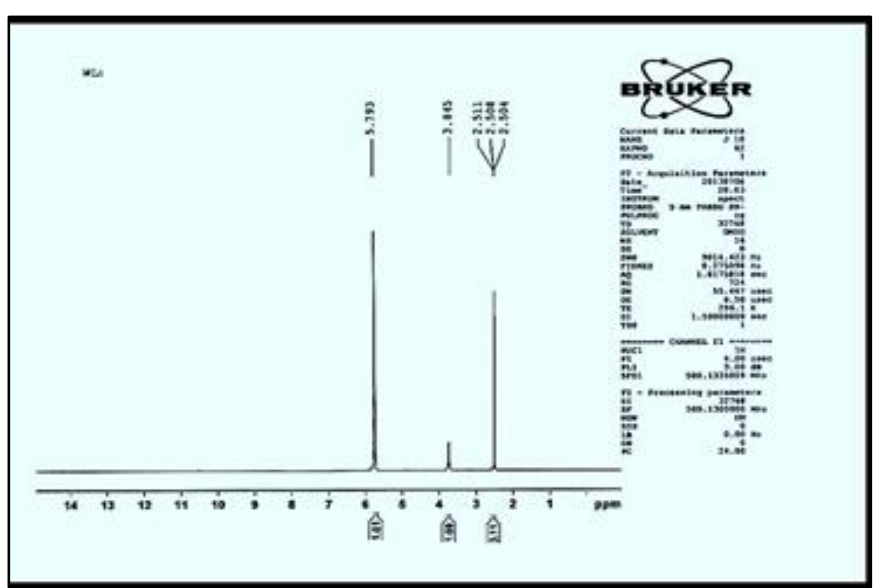

Figure 11 :H1-NMR spectra of the ligand(C4H5N3S2O)

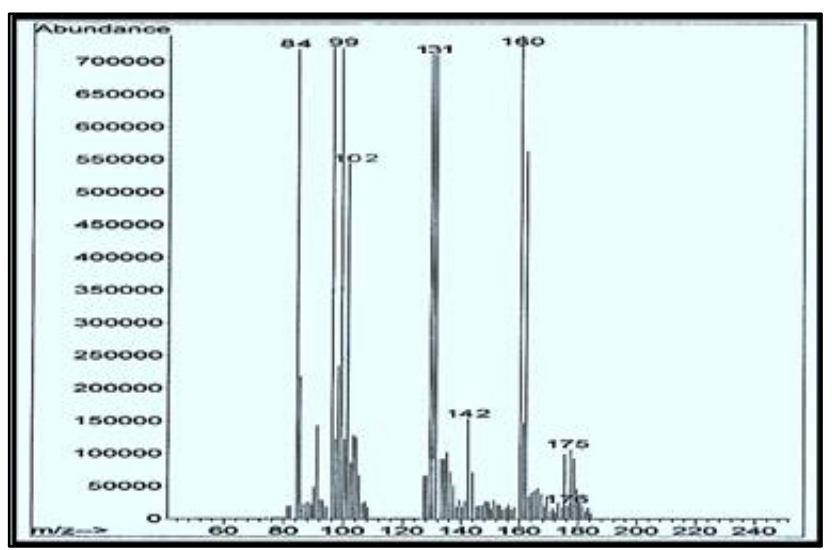

Figure 12: mass spectra of ligand

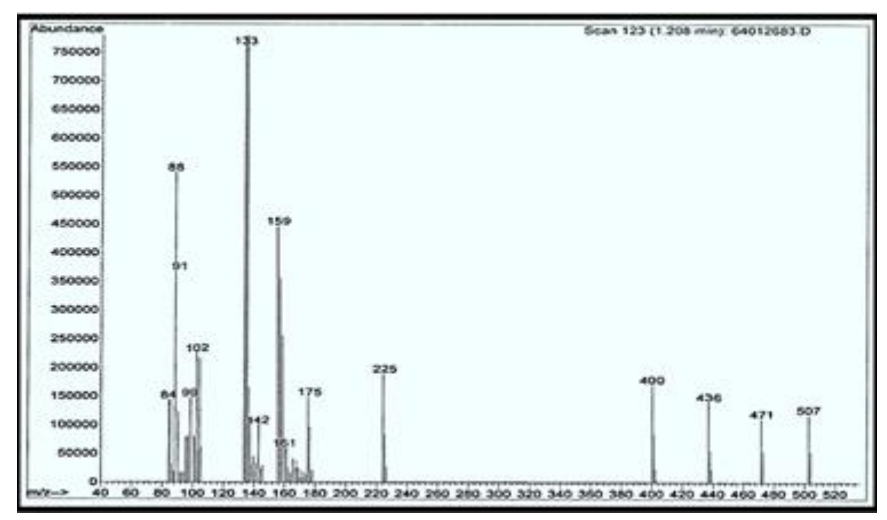

Figure 13: mass spectra of $[\mathrm{Cr}(\mathrm{L}) 2 \mathrm{Cl} 2] \mathrm{Cl}$ 


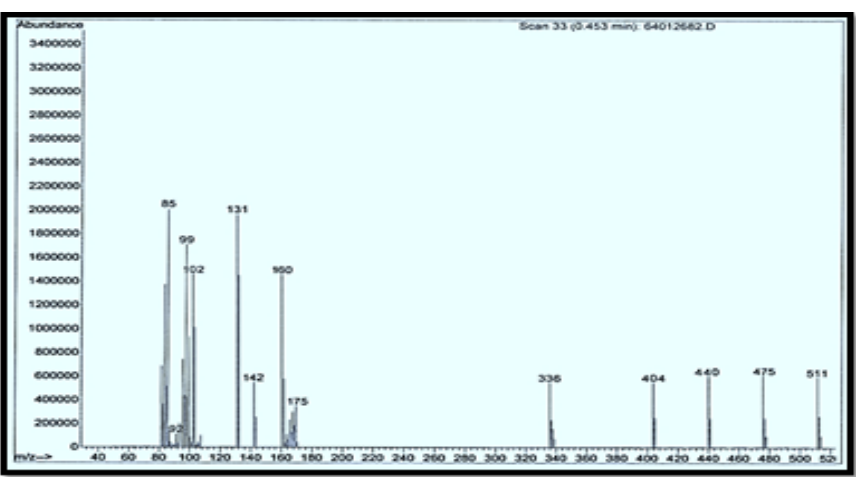

Figure 14: mass spectra of $\left[\mathrm{Fe}(\mathrm{L})_{2} \mathrm{Cl}_{2}\right] \mathrm{Cl}$

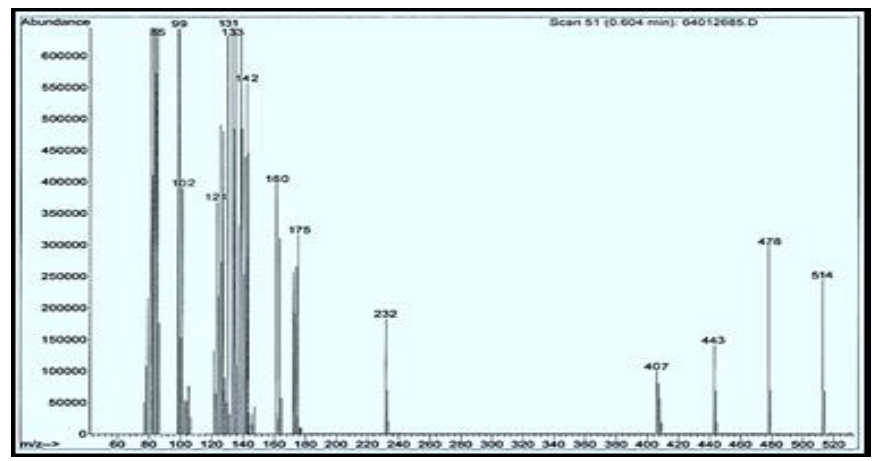

Figure 15: mass spectra of $\left[\mathrm{Co}(\mathrm{L})_{2} \mathrm{Cl}_{2}\right] \mathrm{Cl}$

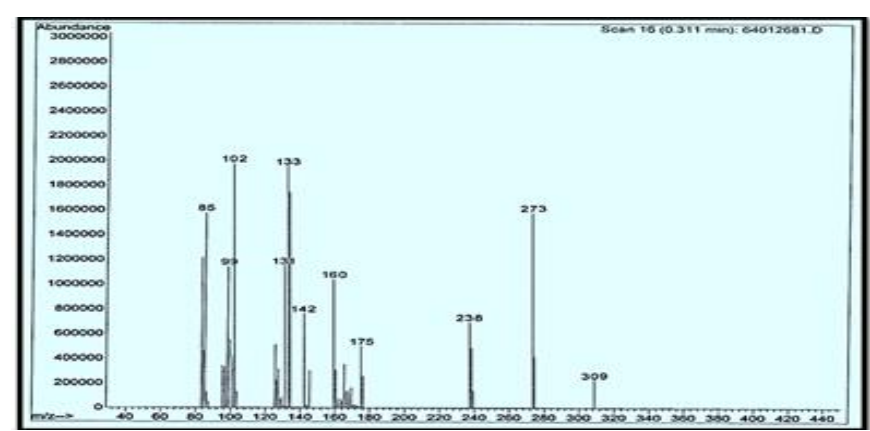

Figure 16: mass spectra of $\left[\mathrm{Cu} \mathrm{LCl}{ }_{2}\right]$

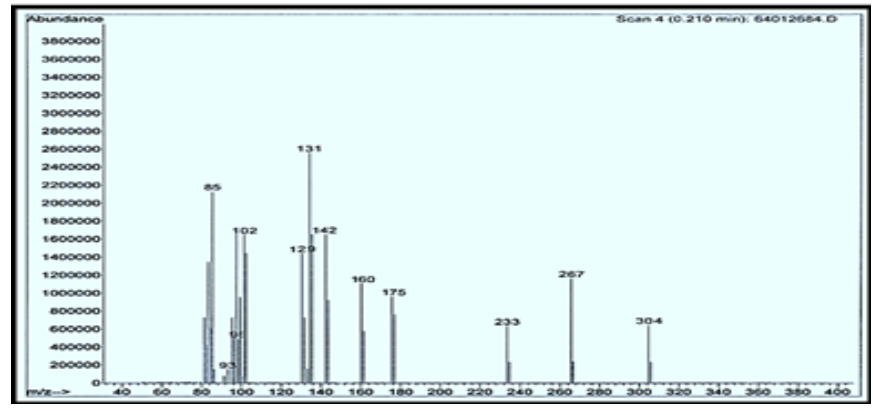

Figure 17: mass spectra of [Ni L Cl2]

\section{References}

1. Demirbas A., Sahin D., demirbas N.and Karaoglu S.A.,Eur J. Med. Chem. 44;2896-2903 (2009).

2. Desai K and Daxi A., Indian J. Pharm Sci.54:183188, (1992).

3.Matysiak J, Nasulewicz A, Pelczynska M, Switalska M, Jaroszewicz I and Opolski A. Eur J. Med Chem.41:475-482,(2006).

4.Azam M, Kumar B, Shalinis S, SurechB, Reddy K and Reddy D., Indian $J$.Pharm Sci.70:672677,(2006).

5.Foroumadi A, Emani S, Hassan Zadeh A, Rajee M, Sokhanvar K and Moshafi H. Bio Org Med Chem Lett.15:4488-4492, (2005).

6. Karia F.D. and Parsania P.H. Asian J. Chem. 11: 991, (1999).

7. Tiwari S.S. and Satsangi R.K., Indian J. Chem. Soc.,LV : 477, (1978).

8. Katritzky A.R., Wang Z. and Offermann R.J.J. ;"Heterocyclic Chemistry", 27- 139, (1990)

9. Eweiss,N.F and Bahajaj,A.A; J.Heterocyclic.Chem. 24,1173-1182(1987) .

10.Nakamato,N."Infrared spectra of inorganic and coordination compound "6th ed;Wiley Intransience; New York (1997)

11. George S.,Acta omarm.,58,119-129,(2008).

12. Ahmad I. and Beg A.Z, Ethnopharmacology J.,74(2),113-123,(2001).

13. Andrews M. , J.antimicrobail chemotherapy J.,48(1),.5-16,(2001). 